\title{
Using Excel's Solver Function To Facilitate Reciprocal Service Department Cost Allocations
}

Wallace R. Leese, California State University, Chico, USA

\begin{abstract}
The reciprocal method of service department cost allocation requires linear equations to be solved simultaneously. These computations are often so complex as to cause the abandonment of the reciprocal method in favor of the less sophisticated and theoretically incorrect direct or step-down methods. This article illustrates how Excel's Solver Function can be used to greatly simplify the reciprocal cost allocation method. Solver Function users will be pleased to see how easy it is to let Excel do the mathematics once the linear equations are formulated.
\end{abstract}

Keywords: Service Department Cost Allocation; Reciprocal Method; Excel Solver Function

\section{INTRODUCTION}

n general, there are three methods available to allocate service department costs to production
departments - the direct, the step-down, and the reciprocal. The reciprocal method "is more accurate
$\ldots$ but is rarely used at this time" (Hilton et al, 2008). Both the direct and the step-down methods are mathematically simpler than the reciprocal method. The use of Excel's Solver Function can significantly simplify the reciprocal cost allocation, thus making this methodology more viable and cost-effective.

\section{FACTS}

A fictitious example, "Leese Company", is used to illustrate this simplification. Leese Company has two service departments $\left(\mathrm{S}_{1}\right.$ and $\left.\mathrm{S}_{2}\right)$ and three production departments $\left(\mathrm{P}_{1}, \mathrm{P}_{2}\right.$, and $\left.\mathrm{P}_{3}\right)$. The pre-allocation costs of the five departments and the percentage of services provided by the service departments to other departments are detailed in Table 1.

Table 1: Data for Illustrating Leese Company Allocations

\begin{tabular}{|l|c|c|c|c|c|}
\hline \multirow{2}{*}{ Service Provider } & \multicolumn{5}{|c|}{ Service User } \\
\cline { 2 - 6 } & $\mathbf{S}_{\mathbf{1}}$ & $\mathbf{S}_{\mathbf{2}}$ & $\mathbf{P}_{\mathbf{1}}$ & $\mathbf{P}_{\mathbf{2}}$ & $\mathbf{P}_{\mathbf{3}}$ \\
\hline $\mathrm{S}_{1}$ & $0 \%$ & $60 \%$ & $30 \%$ & $5 \%$ & $5 \%$ \\
\hline $\mathrm{S}_{2}$ & $40 \%$ & $20 \%$ & $5 \%$ & $10 \%$ & $25 \%$ \\
\hline Pre-Allocation Costs & $\$ 48,000$ & $\$ 60,800$ & $\$ 120,000$ & $\$ 200,000$ & $\$ 250,000$ \\
\hline
\end{tabular}

\section{STEP 1: DETERMINE THE LINEAR EQUATIONS TO BE SOLVED}

$\mathrm{S}_{1}=40 \%\left(\mathrm{~S}_{2}\right)+\$ 48,000$

$S_{1}$ consumes $40 \%$ of the efforts of $S_{2}$ and has pre-allocation costs assigned to it of $\$ 48,000$.

$\mathrm{S}_{2}=60 \%\left(\mathrm{~S}_{1}\right)+20 \%\left(\mathrm{~S}_{2}\right)+\$ 60,800$

$\mathrm{S}_{2}$ has pre-allocation costs assigned to it of $\$ 60,800$ and consumes $60 \%$ of the efforts of $S_{1}$ and $20 \%$ of its own efforts. 


\section{STEP 3: CONFIGURE THE EXCEL SOLVER CALCULATION SECTION - SOLVER CHANGE CELLS}

The solver change cells (C10, D10, E10, F10, and G10) must be formally named within the spreadsheet. To name cell C10, place your cursor over cell C10 and left click your mouse. This will bold the cell boundaries. Now move your cursor to the name box in the upper left hand corner of the spreadsheet. The name box will show $\mathrm{C} 10$ as its name at this time. Move your cursor over the name box and left click your cursor; this will highlight C10 within the Name Box. Now type SDept1 (followed by the Enter key) to assign SDept1 as the name associated with cell C10. Assign cells D10, E10, F10 and G10 as SDept2, Prod1, Prod2, and Prod3, respectively. Values of $\$ 0$ are entered into these named cells. After the Solver Function is run, cell C10, now named SDept1 and having an original value of $\$ 0$, will contain the total costs associated with operating service department $S_{1}$ and cell D10 will contain the total costs associated with operating service department $S_{2}$. In addition, after running the Solver Function, cells E10, named Prod1, F10, named Prod2, and G10, named Prod3, will contain post-allocation costs assigned to these departments. These costs will total $\$ 678,800$ - the sum of the pre-allocation costs associated with all of the departments, both service and production.

\section{STEP 4: CONFIGURE THE EXCEL SOLVER CALCULATION SECTION - SOLVER TARGET FUNCTION}

After the completion of all the cost allocations, all of the original service department costs will be transferred to the three production departments. Therefore, the total costs assigned to these three departments must be equal to $\$ 678,800$. The Solver Target Function cell (H11) communicates to Excel a function to be either maximized, minimized, or, as in this case, to be set equal to a target number. In cell H11, enter the following Excel formula: $=$ Prod1+Prod2+Prod3. Later, as part of the Solver Function, this formula will be set equal to $\$ 678,800$. Excel's Solver Function, using this Target Function, will assign a total of $\$ 678,800$ to the three production departments in a manner which is consistent with the set of linear equations defined earlier and configured below.

\section{STEP 5: CONFIGURE THE EXCEL SOLVER CALCULATION SECTION - SOLVER CONSTRAINT EQUATIONS}

Cells G9, F9, E9, D9, and C9 - the Solver Constraint Equations - must be configured. These five equations will be solved simultaneously with the help of the Solver Function. In cell G9, enter the following Excel formula: $=\mathrm{G} 6+\mathrm{G} 4 * \mathrm{SDept} 1+\mathrm{G} 5 * \mathrm{SDept} 2$. This formula calculates the post-allocation costs associated with Production Department $\mathrm{P}_{3}$. The data and the formula indicate that Production Department $\mathrm{P}_{3}$ has pre-allocation costs assigned to it of $\$ 250,000$ (G6). The data also indicates Production Department $P_{3}$ uses 5\% (cell G4) of the services provided by Service Department $S_{1}$ and $25 \%$ (cell G5) of the services provided by Service Department $S_{2}$. In a similar manner, configure cell F9 with the formula $=\mathrm{F} 6+\mathrm{F} 4 * \mathrm{SDept} 1+\mathrm{F} 5 * \mathrm{SD}$ ept 2 . Then configure cell E9 with the formula $=E 6+E 4 * S D e p t 1+E 5 *$ SDept 2 . Finally, cells D9 and C9 should be configured to contain the formulas $=\mathrm{D} 6+\mathrm{D} 4 * \mathrm{SDept} 1+\mathrm{D} 5 * \mathrm{SDept} 2$ and $=\mathrm{C} 6+\mathrm{C} 4 * \mathrm{SDept} 1+\mathrm{C} 5 * \mathrm{SDept} 2$. Initially, when the above formulas are entered, cells C9, D9, E9, F9, and G9 will display the pre-allocation costs originally associated with each of the departments.

\section{STEP 6: INSTALL EXCEL'S SOLVER FUNCTION IF NOT ALREADY INSTALLED}

To run Excel's Solver Function for this example, open the Excel file configured above. Left click your mouse on the "Data" tab and then left click on the "Solver". If there is no "Solver" to left-click on, then Excel's Solver Function needs to be installed before proceeding. Solver is an add-in program which is not automatically installed when Excel is initially installed. To install Solver, left click on the Office Button in the extreme upper left corner of the Excel sheet configured earlier for the sample data. This click will open a drop-down window. At the bottom of that drop-down window, left click on "Excel Options" which will open another window as shown below. 


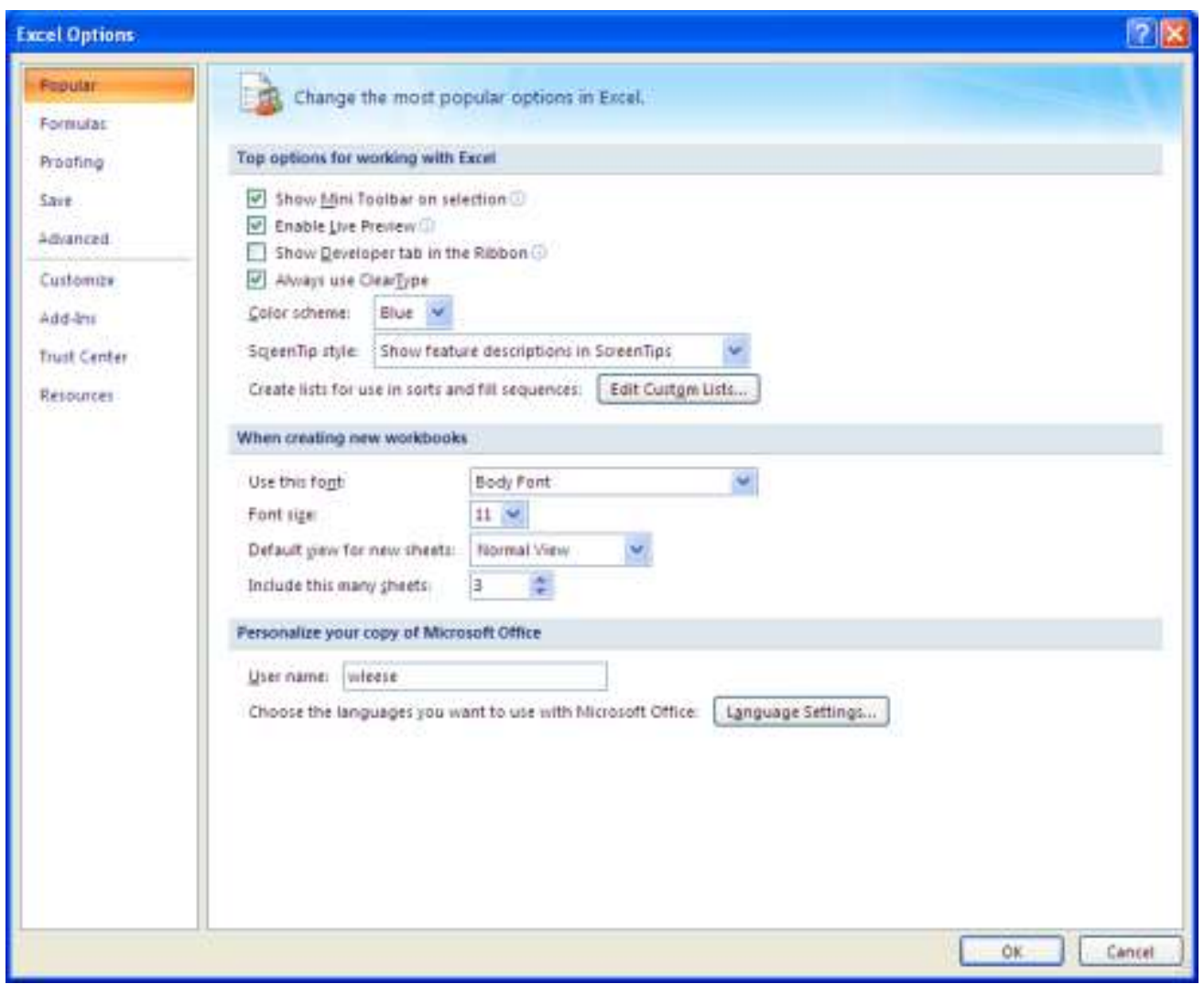

In the left column of that window, left click on "Add-Ins". A listing of add-ins will appear on the right. At the bottom of that listing, left click "Go...". This will open a new drop-down window. Left click in the little box to the left of "Solver Add-in" in the drop-down window as shown below. Left click "OK" to install the Solver Add-in.

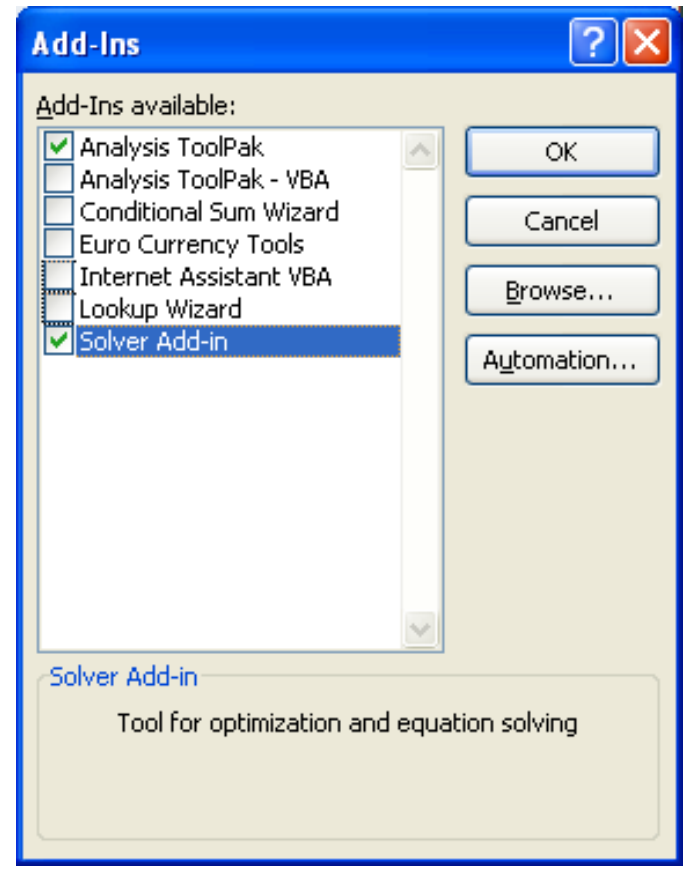




\section{STEP 7: CONFIGURE THE SOLVER FUNCTION DROP-DOWN WINDOW}

To run Excel's Solver Function for this example, open the Excel file configured above. Left click on the "Data" tab and then left click on "Solver". The following drop-down window entitled Solver Parameters will appear.

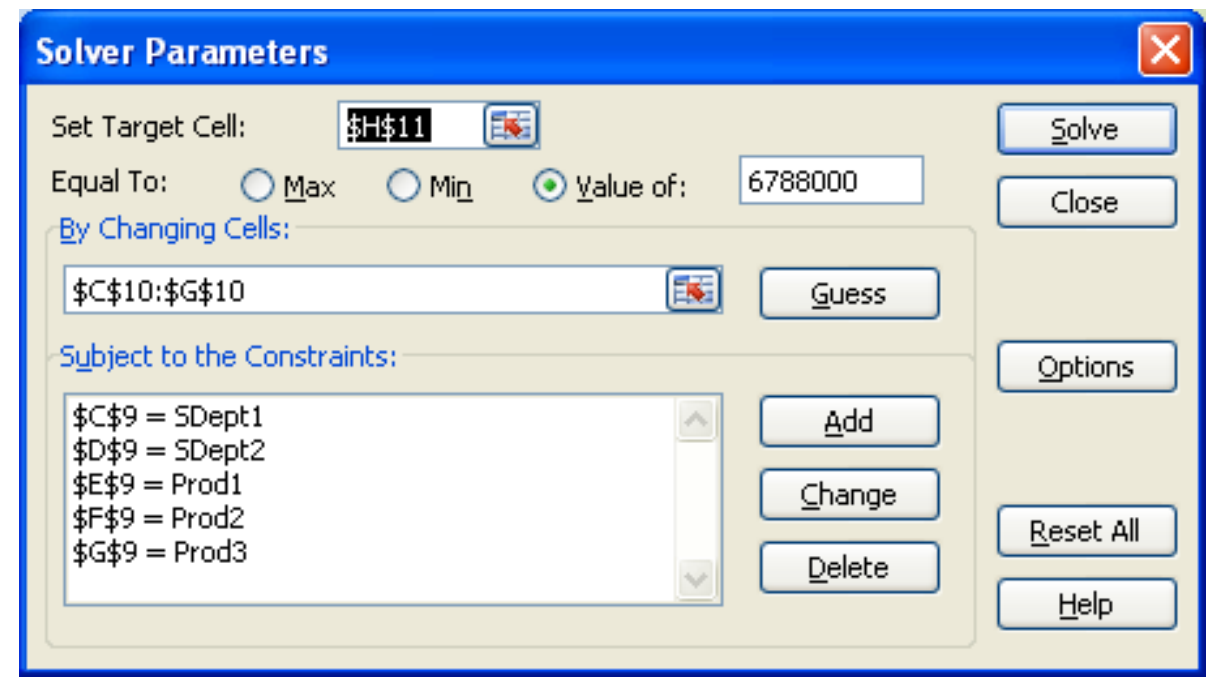

Configure this window to match the window displayed above.

First, set the target cell equal to H11. Second, left click the circle (the radio button) in front of "Value of:". Third, type 678800 as the value we want the target cell to equal at the end of the cost allocation process. Fourth, type "C10:G10" in the "By Changing Cells:" section to identify the changing cells in the Leese example spreadsheet. Fifth, in the "Subject to the Constraints:" section, add each of the five constraints, one at a time. These constraints can be added by clicking on the "Add" button, which will activate a new drop-down window as shown below.

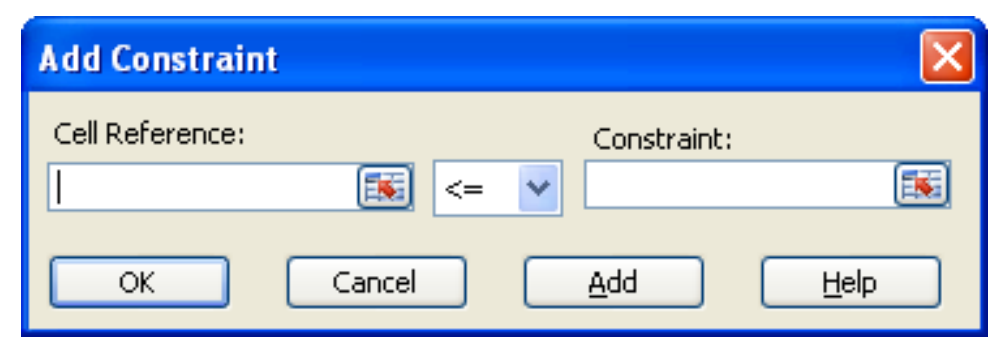

In the Cell Reference section, type "C9" and change " $<=$ " to " $=$ ". In the Constraint section, type "SDept1". Now click the "OK" button to add the constraint to the Solver Parameters' drop-down window. This process defines the first of the five linear equations for Excel's Solver Function to solve simultaneously, C9 = SDept1. The change cell C10, defined as SDept1, has been set equal to the formula entered in C9 during Step 5. The formula contained in cell C9 is: $\mathrm{C} 6+\mathrm{C} 4 * \mathrm{SDept} 1+\mathrm{C} 5 * \mathrm{SDept} 2$. Thus, the first constraint is formulated as $\mathrm{C} 9=\mathrm{SDept} 1$, resulting in $\mathrm{C} 6+\mathrm{C} 4 * \mathrm{SDept} 1+\mathrm{C} 5 * \mathrm{SDept} 2=\mathrm{SDept} 1$.

Repeat this process, adding the four other constraints as follows:

D9 $=$ SDept2, E9 $=$ Prod1, F9 $=$ Prod2, and finally G9 $=$ Prod3. When this process is complete, the Solver Parameters' drop-down window should look like the following. The Solver Function has now been configured. 


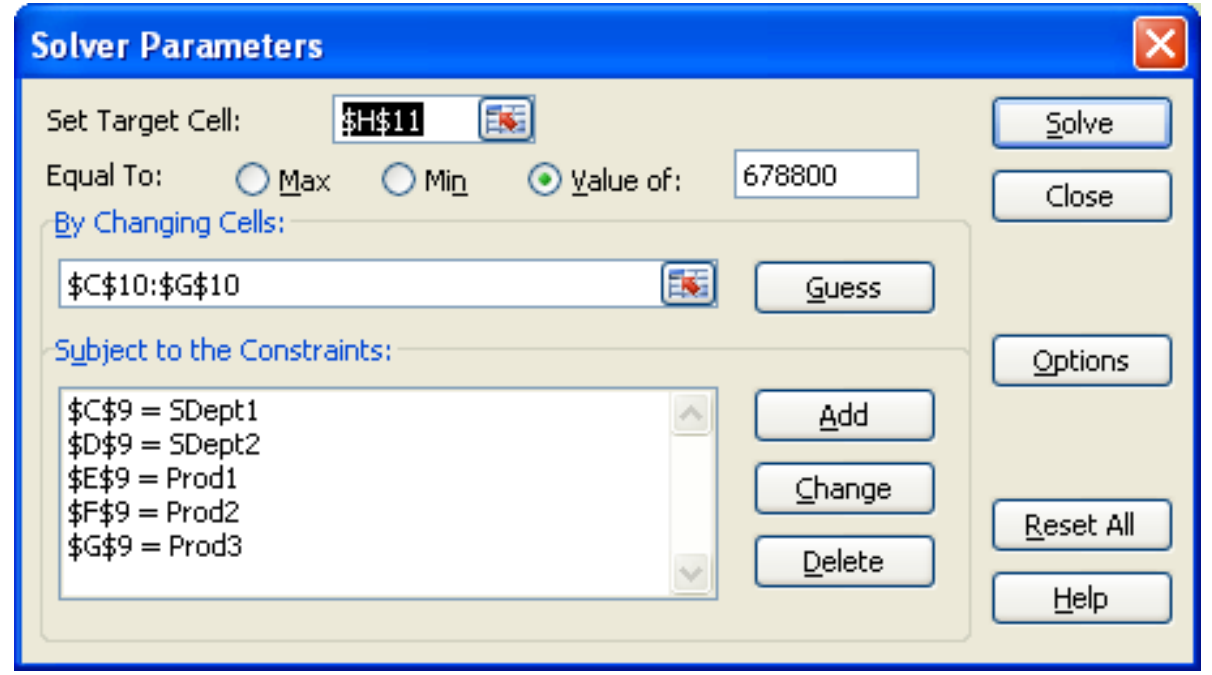

\section{STEP 8: RUN THE SOLVE FUNCTION}

On the configured Solver Parameters' drop-down window, left click on the "Solve" button which is located in the upper right-hand corner of the window. Excel's Solver function will generate the following solution:

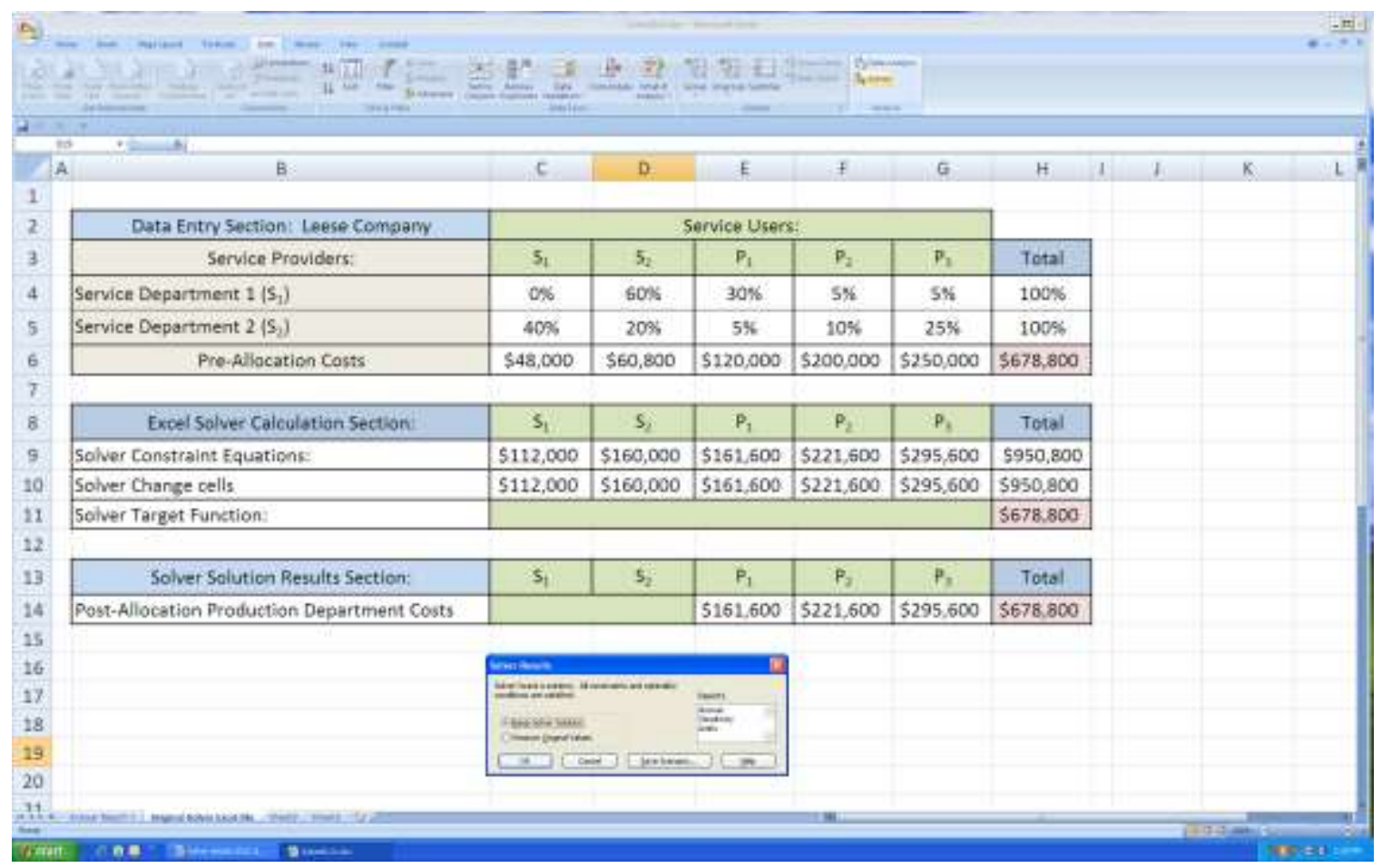

The Solver Solution Results Section now displays post-allocation production department costs of $\$ 161,600$, $\$ 221,600$, and $\$ 295,600$ for departments P1, P2, and P3, respectively. The total pre-allocation dollars of $\$ 678,800$, which were originally assigned to departments $\mathrm{S} 1, \mathrm{~S} 2, \mathrm{P} 1, \mathrm{P} 2$, and P3, are now all assigned to only production departments $\mathrm{P} 1, \mathrm{P} 2$, and $\mathrm{P} 3$. 


\section{CONCLUSION}

As competition encourages managers to become more concerned with accurate service department cost allocations, the use of the reciprocal service department cost allocation method should increase - provided its implementation is not overly complex. However, implementation is viewed as complex and thus this method is rarely used in practice today. Simplification should lead to more use. As shown in this paper, Excel's Solver Function operations can be used to simplify the reciprocal cost allocation process. Reduced complexity, resulting in more use, should enable accounting practitioners to better satisfy management's desire for more accurate cost allocations. As practitioners become more aware of the advantages associated with using Excel's Solver Function as an aid to the reciprocal method, usage of this preferred allocation method should increase and more accurate cost allocations should result.

\section{END NOTES}

1. Note that all service departments are included in the linear equations regardless of whether they perform services for other departments. This approach was used to help readers conceptualize the general approach to the solutions techniques used.

2. Readers of this article are referred to "Using Excel's Matrix Operations to Facilitate Reciprocal Costs Allocations" published in the American Journal of Business Education (December, 2009; Volume 2, Number 9) authored by Drs. Leese and Kizirian. The same fictitious "Leese Company" example was used in that article to illustrate how Excel's matrix operations could be used to solve reciprocal cost allocation problems.

\section{AUTHOR INFORMATION}

Wallace R. Leese earned a BBA degree (Accounting) from Niagara University (1969), a MSA degree (Accounting) (1970) and a Ph.D. (Accounting) (1978) from Arizona State University. He is presently a Professor of Accounting at California State University, Chico. His teaching interests include principles, managerial, intermediate, cost, and advanced cost. He is a CMA. Professor Leese has served CSU, Chico as the Chairman of the Department of Accounting \& Management Information Systems, as the Director of Graduate Business Programs, and as the Associate Dean of the College of Business. Before entering academia, he worked as an auditor for Haskins \& Sells. E-mail: wleese@csuchico.edu

\section{REFERENCES}

1. Blocher, E., David, S., Gary, C., Kung, C., (2008). Cost Management, A Strategic Emphasis. $4^{\text {th }}$ ed. The McGraw-Hill Companies. 454-465.

2. $\quad$ Eldenburg, L. G., Wolcott, S. K., (2011). Cost Management. $2^{\text {nd }}$ ed. John Wiley \& Sons, Inc. 151-155; 300325.

3. Hilton, R., Mayer, W., Selto, F. (2008). Cost Management Strategies for Business Decisions. $4^{\text {th }}$ ed. The McGraw-Hill Companies. 370-397.

4. Horngren, C. T., Datar, S. M., Rajan, M., (2012). Cost Accounting, A Managerial Emphasis. $14^{\text {th }}$ ed. Pearson Prentice-Hall. 550-557.

5. Kinney, M. R., Railborn, C., (2011). Cost Accounting, Foundations and Evolutions. $8^{\text {th }}$ ed. South-Western. 556-565. 
NOTES 